\title{
表面機械加工後のビードオンプレート溶接により発生する 残留応力分布に及ぼす加工条件の影響十
}

伊原 涼平* 望月 正人*

\author{
Effect of Processing Conditions on Residual Stress Distributions \\ by Bead-on-plate Welding after Surface Machining
}

by

\author{
Ryohei IHARA*and Masahito Mochizuki*
}

\begin{abstract}
Residual stress is important factor for stress corrosion cracking (SCC) that has been observed near the welded zone in nuclear power plants. Especially, surface residual stress is significant for SCC initiation. In the joining processes of pipes, butt welding is conducted after surface machining. Residual stress is generated by both processes, and residual stress distribution due to surface machining is varied by the subsequent butt welding. In previous paper, authors reported that residual stress distribution generated by bead on plate welding after surface machining has a local maximum residual stress near the weld metal. The local maximum residual stress shows approximately $900 \mathrm{MPa}$ that exceeds the stress threshold for SCC initiation. Therefore, for the safety improvement of nuclear power plants, a study on the local maximum residual stress is important. In this study, the effect of surface machining and welding conditions on residual stress distribution generated by welding after surface machining was investigated. Surface machining using lathe machine and bead on plate welding with tungsten inert gas (TIG) arc under various conditions were conducted for plate specimens made of SUS316L. Then, residual stress distributions were measured by X-ray diffraction method (XRD). As a result, residual stress distributions have the local maximum residual stress near the weld metal in all specimens. The values of the local maximum residual stresses are almost the same. The location of the local maximum residual stress is varied by welding condition. It could be consider that the local maximum residual stress is generated by same generation mechanism as welding residual stress in surface machined layer that has high yield stress.
\end{abstract}

\section{Key words:}

Residual stress, XRD, Surface machining, Bead on plate welding, Manufacturing processes, Austenitic stainless steel

\section{1 緒言}

2011 年 3 月の東日本大震災以降, 将来的な原子力発電 のあり方が問われるようになったが，安定的な電力供給 の観点から，プラントの安全性を確保した上で原子力発 電の利用が再開されつつある。この原子力プラントにお ける安全性向上のため原因解明が望まれる問題の一つと して, 応力腐食割れ（Stress Corrosion Cracking: SCC）が挙 げられる.SCC は沸騰水型原子力発電プラントの低炭素 オーステナイト系ステンレス鋼 SUS316L 製の再循環系配 管等の溶接部近傍に顕在化している ${ }^{1)}$. SCC が顕在化し た構造物に対しては維持規格 ${ }^{2}$ に代表されるき裂進展解 析により，その健全性が確保されている．SCC はその特 性から, 発生過程と進展過程に分けて考えられる場合が 多く, この発生過程と進展過程の境界は $1 \mathrm{~mm}$ 程度のき 裂深さであるとされている ${ }^{3)}$.さらに, 構造物の寿命に対 してはSCC の発生過程がより大きな影響を有するとされ ている ${ }^{4)}$ こから, 原子力プラントの安全性向上のために は, SCC 発生に関して検討を行うことが重要となる.

SCC は材料, 環境, 力学的要因の重畳により発生する とされているが，非鋭敏化材として開発された SUS316L 鋼においては，以前まで主要因とされてきた鋭敏化はほ
ぼ確認されなかったことから, 力学的要因としての残留 応力に相対的な注目が集まっている. 残留応力は配管施 工である表面機械加工および溶接により発生することが 知られており, 配管の溶接接合過程では, 表面機械加工 後に突合せ溶接が施される。著者らは前報 ${ }^{5}$ において, SUS316L 鋼製の板材に対して表面機械加工後にビードオ ンプレートを施した際の表面残留応力分布は，溶接金属 近傍において $900 \mathrm{MPa}$ 程度の極大残留応力を有すること を明らかにした，また，この残留応力分布は，溶接金属 近傍を除いて，表面機械加工，ビードオンプレート溶接 のみにより発生する残留応力分布を加算したような分布 を示したことから，両施工を施した後の残留応力分布は それぞれの施工により発生する残留応力分布に影響を受 けることが考えられる，ここで，高温高圧水環境中での $\mathrm{SCC}$ 発生応力のしきい值はおよそ $600 \mathrm{MPa}$ であるとの報 告 ${ }^{6}$ がなされている. 極大残留応力はこのしきい值を上回 っていることから，SCC 発生に関して重要な因子である と考えられる。したがって，原子力発電プラントの更な る安全性向上のためには, SCC 発生応力のしきい值を下 回る程度に極大残留応力を制御することが重要であり， そのためには，極大残留応力に及ぼす各施工条件の影響

$\dagger$ 原稿受理 平成 25年 10月 9日 Received Oct. 9, $2013 \quad$ C2014 The Society of Materials Science, Japan

* 正 会員 大阪大学大学院工学研究科 ₹565-0871 吹田市山田丘 Graduate school of Eng., Osaka Univ., Yamadaoka, Suita, 565-0871 
の把握, さらには極大残留応力の発生機構に関する検討 が有用となる。

本研究では，極大残留応力值およびその発生位置に及 ぼす施工条件の影響を検討することを目的として， SUS316L 鋼製の板材に対して, 種々の施工条件のもと表 面機械加工およびビードオンプレート溶接を施し，X 線 回折法（X-ray Diffraction Method: XRD）を用いた表面残 留応力分布の測定を行った。 さらに，得られた結果を基 に, 極大残留応力の発生機構に関して考察を行った.

\section{2 実 験 方 法}

\section{$2 \cdot 1$ 供試材および施工条件}

供試材は前報と同様，Table 1 に示した化学組成，およ び Table 2 に示した機械的特性を有する低炭素オーステナ イト系ステンレス鋼 SUS316L であり, 試験体の寸法は 150 $\mathrm{mm}(l) \times 100 \mathrm{~mm}(w) \times 8 \mathrm{~mm}(t)$ である. 試験体に対して, $1050^{\circ} \mathrm{C}$ で $1 \mathrm{~h}$ の溶体化処理を行った後に, 縦旋盤装置を 用いた表面機械加工を施し，さらに，試験体中央の長手 方向に TIG アークを用いたビードオンプレート溶接を施 した. 本研究での施工を模式的に表した図を Fig. 1 に示す. 表面機械加工条件として，切削速度を $45,100 \mathrm{~m} / \mathrm{min}$, 送 り速度を $0.05,0.1,0.3 \mathrm{~mm} / \mathrm{rev}$ ，切込みを $0.1 \mathrm{~mm}$ とした. 溶接条件として, 電流 $120,200 \mathrm{~A}$, 溶接速度 $2 \mathrm{~mm} / \mathrm{s}$, 溶接 長 $130 \mathrm{~mm}$ ，アーク長 $3 \mathrm{~mm}$ とし，溶接時のシールドガス は流量 $15 \mathrm{l} / \mathrm{min}$ とした $\mathrm{Ar}$ ガスを用いた。施工条件をまと めたものを Table 3 に示す. 簡便のため, 表面機械加工時 の切削速度 $V$, 送り速度 $f$, および溶接入熱 $Q$ を用いて, Table 3 に示すように $\mathrm{M}(V-f)+\mathrm{W}(Q)$ と各試験体の名称 を定めており, $Q$ は溶接電流が $120 \mathrm{~A}$ の条件を SQ, $200 \mathrm{~A}$ の条件を LQ とした.また, 比較のため, 表面機械加工の み，溶接のみの場合に対しても残留応力測定を行ってお

り, これらの名称はそれぞれ $\mathrm{M}(V-f), \mathrm{W}(Q)$ とした.

\section{$2 \cdot 2$ 残留応力測定法}

各施工を施した後，表面残留応力測定を行った。測定 は2D 法 ${ }^{7)}$ を用いた XRD により行い, 装置は Bruker AXS 社製の D8 discover with GADDS を用いた。測定条件を Table 4 に示す. この際, 測定精度向上のため, Fig. 1 に示
した座標系における $x, \omega$ 軸に対して多軸摇動を行った. 本 研究では平面応力状態を仮定しており, 解析に必要な弾 性定数およびポアソン比は Kröner モデル ${ }^{8)}$ にり見積も った $E_{220}=209.78 \mathrm{GPa}, v_{220}=0.278$ を用いた。測定領域は, Fig. 1 に示すように, 試験体長手方向の中央部である. 測 定間隔は, SQの溶接条件に対して溶接中心から溶接直交 方向に $20 \mathrm{~mm}$ までを $1 \mathrm{~mm}$ 閒隔, その後は $5 \mathrm{~mm}$ 間隔で, LQ の溶接条件に対して溶接中心から溶接直交方向に 25 $\mathrm{mm}$ までを $1 \mathrm{~mm}$ 間隔，その後は $5 \mathrm{~mm}$ 間隔で行った. な お, EBSD 法により得られた試験体の平均結晶粒径は 47.3 $\mu \mathrm{m}$ であった。
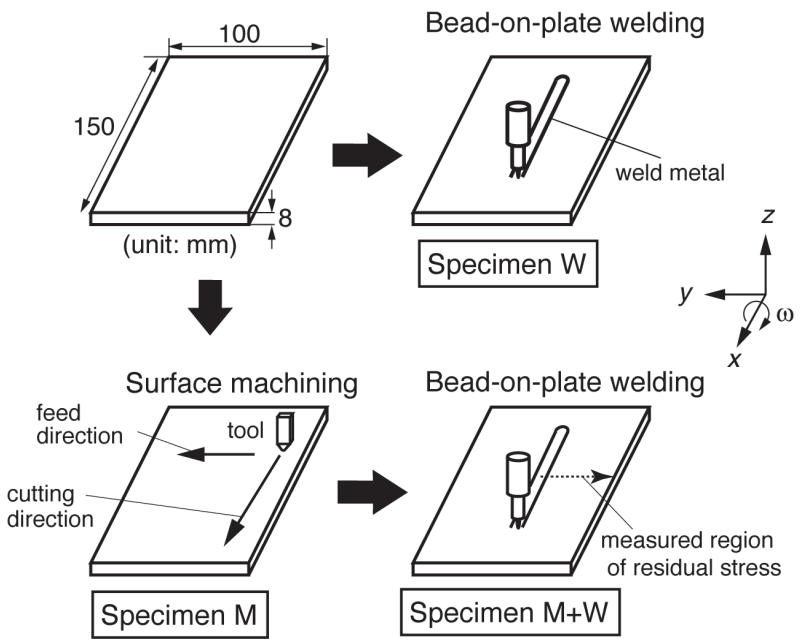

Fig. 1 Preparation of test specimens.

Table 4 XRD conditions for residual stress measurement.

\begin{tabular}{|c|c|}
\hline Wave length $(\mathrm{nm})$ & $0.2291(\mathrm{CrK} \alpha)$ \\
\hline Power $(\mathrm{kV}, \mathrm{mA})$ & 36,88 \\
\hline Beam size $(\mathrm{mm})$ & $\phi 1$ \\
\hline Diffraction peak $(\mathrm{deg})$ & $128(220)$ \\
\hline Measuring time $(\mathrm{s})$ & WM: $80 \times 21$ frame \\
\hline Rocking & $x$ axis: $\pm 2 \mathrm{~mm}, \omega$ axis: $\pm 4^{\circ}$ \\
\hline
\end{tabular}

WM: weld metal, BM: base metal

Table 1 Chemical composition of SUS316L (mass \%).

\begin{tabular}{|c|c|c|c|c|c|c|c|c|c|c|c|}
\hline C & $\mathrm{Si}$ & $\mathrm{Mn}$ & $\mathrm{P}$ & $S$ & $\mathrm{Ni}$ & $\mathrm{Cr}$ & Mo & $\mathrm{Fe}$ & Y.S. (MPa) & T.S. (MPa) & EL. (\%) \\
\hline 0.019 & 0.66 & 1.19 & 0.033 & 0.001 & 12.11 & 17.41 & 2.05 & Bal. & 278 & 540 & 61 \\
\hline
\end{tabular}

Table 3 Surface machining and bead on plate welding conditions.

\begin{tabular}{|c|c|c|c|c|c|c|c|}
\hline \multirow[b]{2}{*}{ Case } & \multirow[b]{2}{*}{ Name } & \multicolumn{3}{|c|}{ Surface machining using lathe machine } & \multicolumn{3}{|c|}{ Bead on plate welding with TIG arc } \\
\hline & & $\begin{array}{l}\text { Cutting speed } \\
(\mathrm{m} / \mathrm{min})\end{array}$ & $\begin{array}{l}\text { Feed rate } \\
(\mathrm{mm} / \mathrm{rev})\end{array}$ & $\begin{array}{l}\text { Cutting depth } \\
(\mathrm{mm})\end{array}$ & $\begin{array}{l}\text { Current } \\
\text { (A) }\end{array}$ & $\begin{array}{l}\text { Welding speed } \\
\qquad(\mathrm{mm} / \mathrm{s})\end{array}$ & $\begin{array}{c}\text { Arc length } \\
(\mathrm{mm})\end{array}$ \\
\hline 1 & $\mathrm{M}(45-0.1)+\mathrm{W}(\mathrm{SQ})$ & 45 & 0.1 & \multirow{5}{*}{0.1} & 120 & \multirow{5}{*}{2} & \multirow{5}{*}{3} \\
\hline II & $\mathrm{M}(45-0.05)+\mathrm{W}(\mathrm{SQ})$ & 45 & 0.05 & & 120 & & \\
\hline III & $M(45-0.3)+W(S Q)$ & 45 & 0.3 & & 120 & & \\
\hline IV & $\mathrm{M}(45-0.1)+\mathrm{W}(\mathrm{LQ})$ & 45 & 0.1 & & 200 & & \\
\hline $\mathrm{V}$ & $\mathrm{M}(100-0.1)+\mathrm{W}(\mathrm{LQ})$ & 100 & 0.1 & & 200 & & \\
\hline
\end{tabular}




\section{3 残留応力の測定結果および考察}

\section{$3 \cdot 1$ 残留応力測定結果}

溶接条件を SQ とした, Case I III の試験体に対して表 面残留応力分布測定を行った結果を，それぞれ Fig. $2 \sim 4$ に示す.SQの溶接条件におけるビード幅は $6.1 \mathrm{~mm}$ であ り，図中に溶融境界として示した。 Fig. 2 より， $x$ 方向の 残留応力分布は溶接金属において降伏応力程度の引張残 留応力を示すとともに, 溶接中心からの距離とともに増 加し, $6 \mathrm{~mm}$ の位置において $900 \mathrm{MPa}$ 程度の極大残留応力 を示した。 そして，距離とともに減少することにより， 溶接中心からの距離が $45 \mathrm{~mm}$ とした端部において 300 $\mathrm{MPa}$ 程度の引張残留応力を示した. $y$ 方向の残留応力分布 に関しても，溶接中心からの距離とともに徐々に増加し， $15 \mathrm{~mm}$ 付近において $300 \mathrm{MPa}$ 程度の極大值を有し，その 後は距離とともに減少する結果が得られた。この結果は 前報において得られた結果と同様の傾向を示している.

Fig. 3, 4 においても，同様の傾向が得られており， $x$ 方向 の残留応力分布は, $6 \mathrm{~mm}$ 付近において $900 \mathrm{MPa}$ 程度の 值を有する極大残留応力を示した．しかしながら，極大 残留応力が発生した $6 \mathrm{~mm}$ の位置から, $10 \mathrm{~mm}$ 程度までの 残留応力分布に注目すると, その領域での減少勾配に相
違が生じていることが確認でき, その結果, 端部の残留 応力では, M(45-0.05) + W(SQ) の場合において $100 \mathrm{MPa}$ 程度, M(45-0.3)+W(SQ) の場合において $450 \mathrm{MPa}$ 程度の 引張残留応力を示寸結果となった。 $y$ 方向の残留応力分 布に関しては，各施工条件において值が大きく異なって おり, Fig. 3 に示した M(45-0.05) +W(SQ) の結果では表面 機械加工および溶接のみとした M(45-0.05), W(SQ) の残 留応力分布と大きな差は見られない。また，Fig. 4 に示し た M(45-0.3) + W(SQ) の結果においては, M(45-0.1) + $\mathrm{W}(\mathrm{SQ})$ の結果と同様, 溶接中心から $15 \mathrm{~mm}$ 付近において 極大残留応力が確認できるが, その值は $550 \mathrm{MPa}$ 程度と, $\mathrm{M}(45-0.1)+\mathrm{W}(\mathrm{SQ})$ の結果よりも大きな值を示した。この $\mathrm{M}(45-0.3)+\mathrm{W}(\mathrm{SQ})$ における $\sigma_{x}, \sigma_{y}$ の結果は，前報で示し た $\mathrm{M}(100-0.1)+\mathrm{W}(\mathrm{SQ})$ の結果とほぼ同様の值および分布 が得られた. Fig. 5, 6 に溶接条件を LQ とした, Case IV, V の表面残留応力の測定結果を示す.ここで，LQの条件に おいては，多軸摇動を用いても十分な回折が得られず, 溶接金属における残留応力の測定が困難であった。しか しながら, 本検討では, 溶接熱影響部近傍に発生する極 大残留応力に関して主に検討を行っている. そのため, 溶接金属の残留応力測定は比較的重要でないことから,

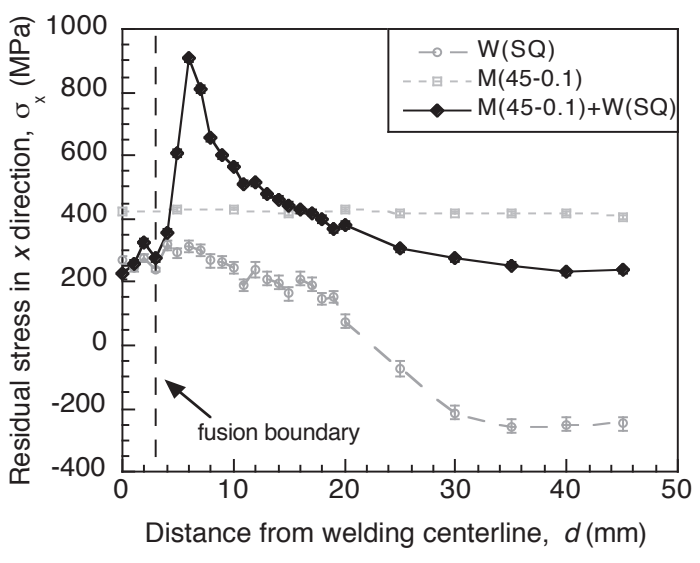

(a) Residual stress in $x$ direction

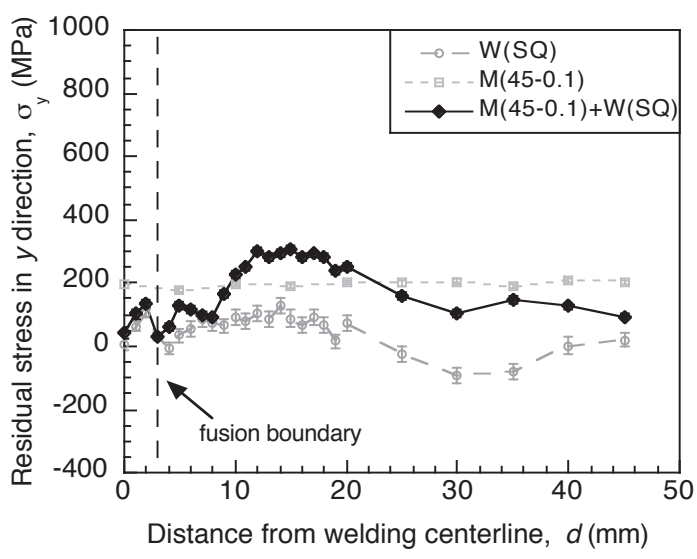

(b) Residual stress in $y$ direction

Fig. 2 Comparison of surface residual stress distributions in specimens W(SQ), M(45-0.1) and M(45-0.1)+W(SQ).

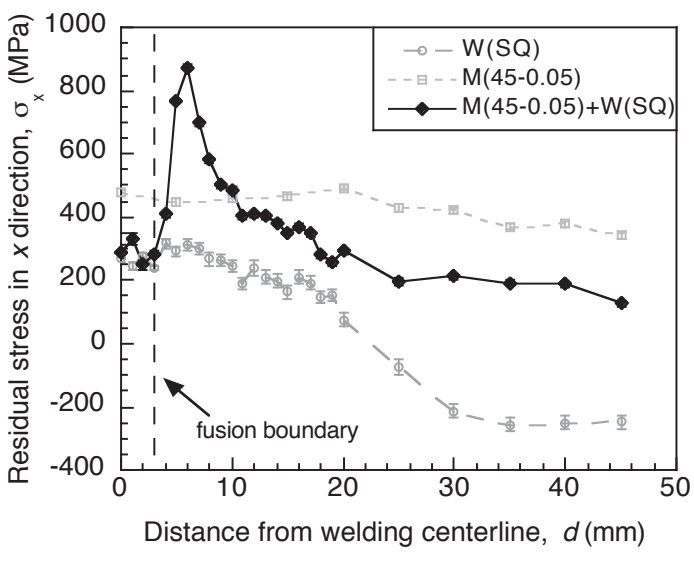

(a) Residual stress in $x$ direction

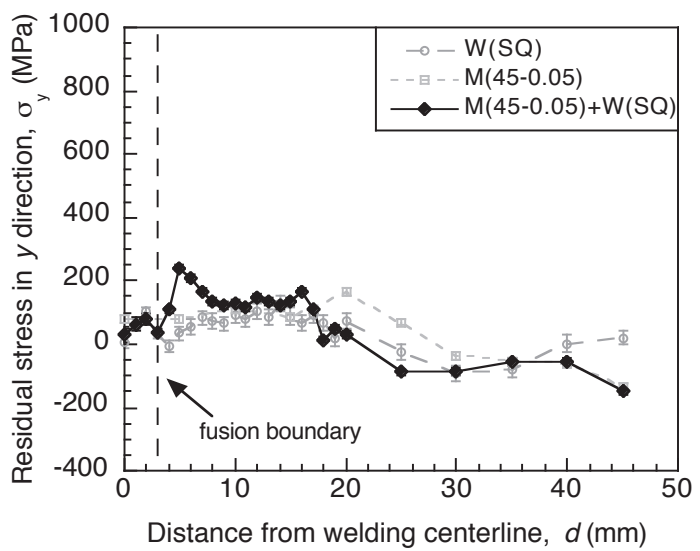

(b) Residual stress in $y$ direction

Fig. 3 Comparison of surface residual stress distributions in specimens W(SQ), M(45-0.05) and M(45-0.05)+W(SQ). 


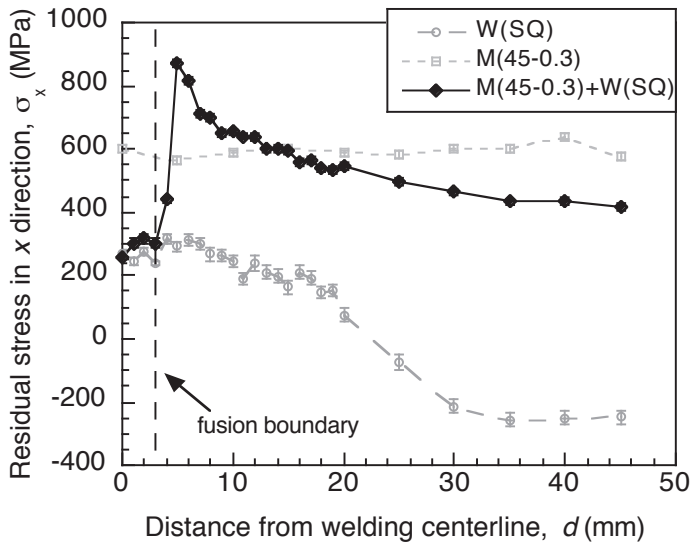

(a) Residual stress in $x$ direction

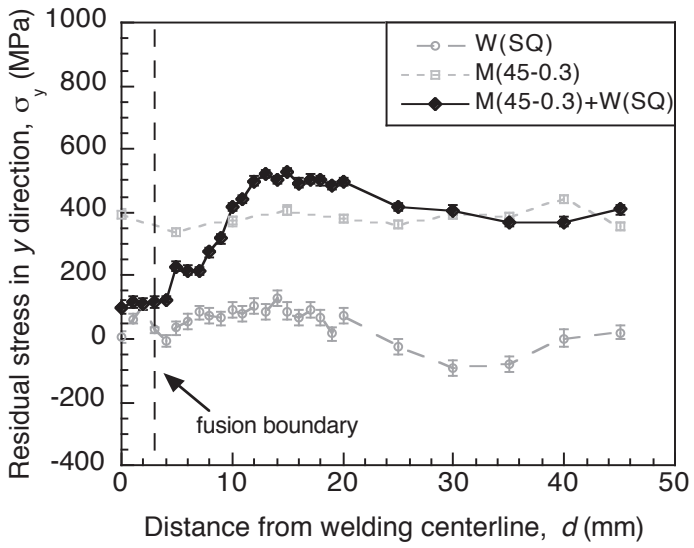

(b) Residual stress in $y$ direction

Fig. 4 Comparison of surface residual stress distributions in specimens W(SQ), M(45-0.3) and M(45-0.3)+W(SQ).

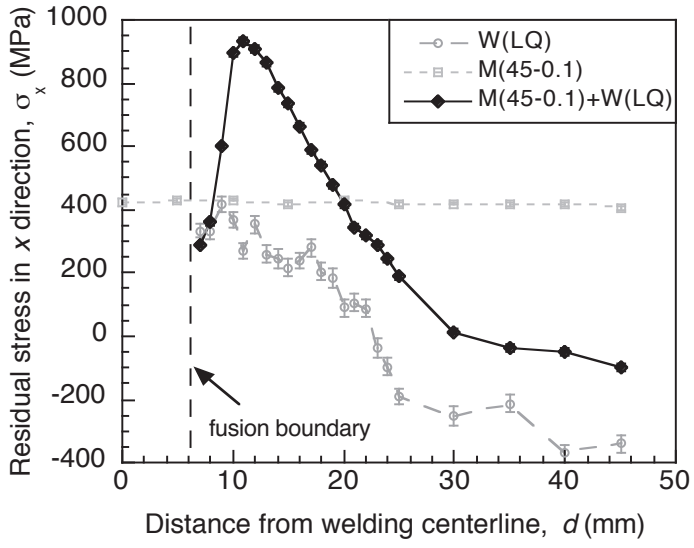

(a) Residual stress in $x$ direction

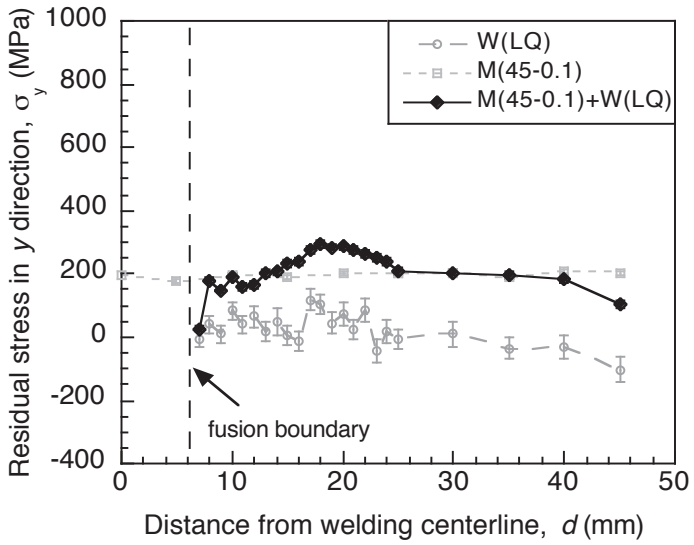

(b) Residual stress in $y$ direction

Fig. 5 Comparison of surface residual stress distributions in specimens W(LQ), M(45-0.1) and M(45-0.1)+W(LQ).

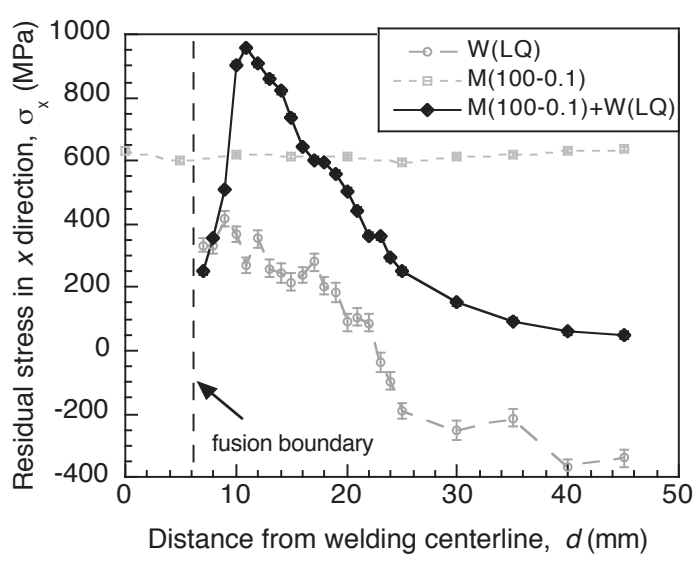

(a) Residual stress in $x$ direction

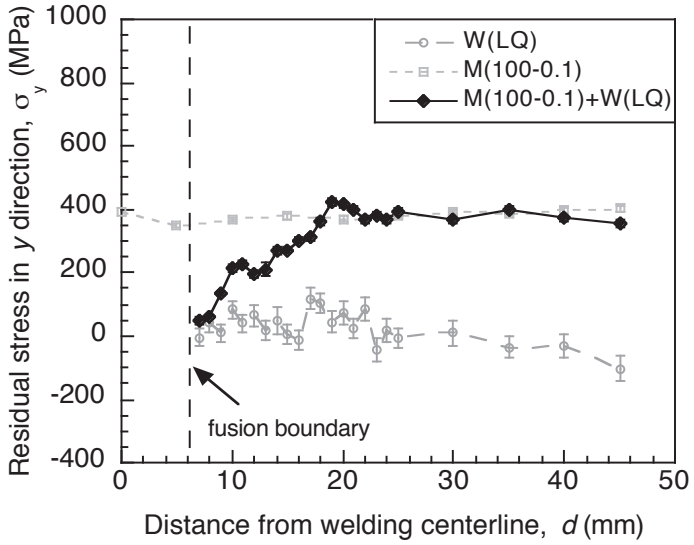

(b) Residual stress in $y$ direction

Fig. 6 Comparison of surface residual stress distributions in specimens W(LQ), M(100-0.1) and M(100-0.1)+W(LQ).

溶融境界以降の残留応力の測定を行った。なお，LQの条 件におけるビード幅は $12.2 \mathrm{~mm}$ であり, 同様に溶融境界 として図中に示した. Fig. 5,6より, どちらの試験体にお いても, $x$ 方向の残留応力は溶接中心からの距離とともに 増加し, $11 \mathrm{~mm}$ において $950 \mathrm{MPa}$ 程度の極大残留応力を
示した。その後, 残留応力分布は距離とともに減少する が，およそ $20 \mathrm{~mm}$ 以降の減少勾配は，Fig. 2 ４に示した 溶接条件が SQ の場合と比較して大きな勾配を有してい ることが分かる. その結果, 端部の残留応力は, M(45-0.1) $+\mathrm{W}(\mathrm{LQ})$ の条件において-100 MPa 程度, M(100-0.1) + 
W(LQ) の条件において $100 \mathrm{MPa}$ 程度の值を示す結果が得 られた. $y$ 方向の残留応力分布に関しては，溶接条件を SQ とした場合とほぼ同様の傾向が得られているが，極大 残留応力の発生位置はおよそ $20 \mathrm{~mm}$ となった.

\section{$3 \cdot 2$ 極大残留応力の発生に関する考察}

著者らは前報において, 表面機械加工後にビードオン プレート溶接を行った場合の表面残留応力分布に関して, 溶接により生じる残留応力分布は表面機械加工により発 生した残留応力分布の存在下において平衡を保つため, 表面機械加工時の残留応力分布に溶接時の残留応力分布 を加算した分布が成り立つと考えた。ここで，SQ の溶接 条件に対してはおよそ $12 \mathrm{~mm}, \mathrm{LQ}$ の溶接条件に対しては およそ $20 \mathrm{~mm}$ 以降の残留応力分布に注目寸ると，表面機 械加工条件の違いにより, それ以降の分布が異なること が確認できる。これは表面機械加工により発生した残留 応力の影響によるものであり，これらの領域に関しては 上述の残留応力分布の加算が成立しているものと考えら れる。しかしながら，極大残留応力に注目すると，本報 において表面機械加工時の残留応力 + 溶接時の残留応 力 $($ 約 $300 \mathrm{MPa})=$ 極大残留応力 $($ 約 $900 \mathrm{MPa}$ ）が成立す るのは, Fig. 4 に示した M(45-0.3)+W(SQ), Fig. 6 に示し た $\mathrm{M}(100-0.1)+\mathrm{W}(\mathrm{LQ})$ の条件における， $\sigma_{x}=600 \mathrm{MPa} の$ 場合のみであり，このような考えでは説明できない.

一般に, ビードオンプレート溶接時の残留応力の発生 機構は, 両端固定棒モデル ${ }^{9}$ により考えることが可能であ る。両端固定棒に単調増加・減少する熱サイクルを付与 した場合の, 温度と溶接線方向 $(x$ 方向 $)$ 応力の関係を表 した模式図を Fig. 7 に示す.ここで，表面機械加工後に溶 接を行った場合，溶接金属近傍においては溶接熱サイク ルに伴う回復・再結晶により硬さが減少するが，極大残 留応力が発生する領域では, $300 \mathrm{HV}$ 前後の值を有する, ほぼ表面機械加工ままの硬さが残存する ${ }^{5)}$. 硬さは，一般 に，降伏応力や相当塑性ひずみと相関関係を有すること

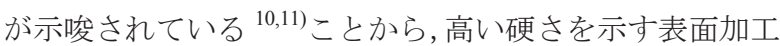
層では, 母材と比較して, 高い降伏応力を有する領域と
考えることができる。このような領域を対象として，両 端固定棒に上記の熱サイクルを付与した場合の溶接線方 向における応力履歴を合わせて Fig. 7 に示している. Fig. 7 に破線で示した溶接のみの場合を考えると，まず，温度 上昇とともに無応力状態から圧縮応力が発生することで 降伏に至る。降伏後は温度上昇により低下寸る降伏応力 とともに応力は減少するが, 最高温度 $T_{\max }$ に達し, 温度 が低下寸ることにより引張応力が発生する。この引張応 力により再度降伏に達し, 応力は温度低下により上昇す る降伏応力に依存して増加する。一方, Fig. 7 に実線で示 した表面機械加工後にビードオンプレート溶接を行った 場合，表面機械加工により発生した引張残留応力，およ び高い降伏応力を有する表面加工層の影響により, 温度 上昇時の圧縮応力による降伏は, 溶接のみの場合と比較 して大きな温度上昇を要する. 降伏後の応力は, 表面加 工層での降伏応力の温度依存性により減少し, 最高温度 $T_{\text {max }}$ に到達後は, 溶接のみの場合と同様に温度低下ととも に引張応力が発生することにより降伏が生じる。降伏後 は温度低下に伴う表面加工層での降伏応力の上昇により 引張応力が増加する. ここで, Fig. 7 における両端の剛体 壁は，溶接時に急加熱・急冷された領域の熱膨張が，温 度が上昇していない母材部に拘束される影響を表したも のである。したがって，試験体全体が均一の温度となる 平均温度上昇 $T_{\text {ave }}$ に達すると剛体壁の効果はなくなり, $T_{\text {ave }}$ からの冷却はほぼ自由に収縮できる状態となる.すな わち, $T_{\text {ave }}$ 到達後は収縮に伴う応力は生じないため一点鎖 線で示した降伏応力とともに上昇せず，温度低下による ヤング率の回復に起因する，比較的小さな応力の上昇の みが発生すると考えられる。したがって，表面機械加工 後のビードオンプレート溶接により発生する極大残留応 力は, 高い降伏応力を有する表面加工層において, 溶接 のみを施した際の残留応力と同様のメカニズムにより発 生するものと推察される.

次に，本検討において得られたような初期残留応力が 異なる場合，表面加工層での加工硬化が違う場合に関し

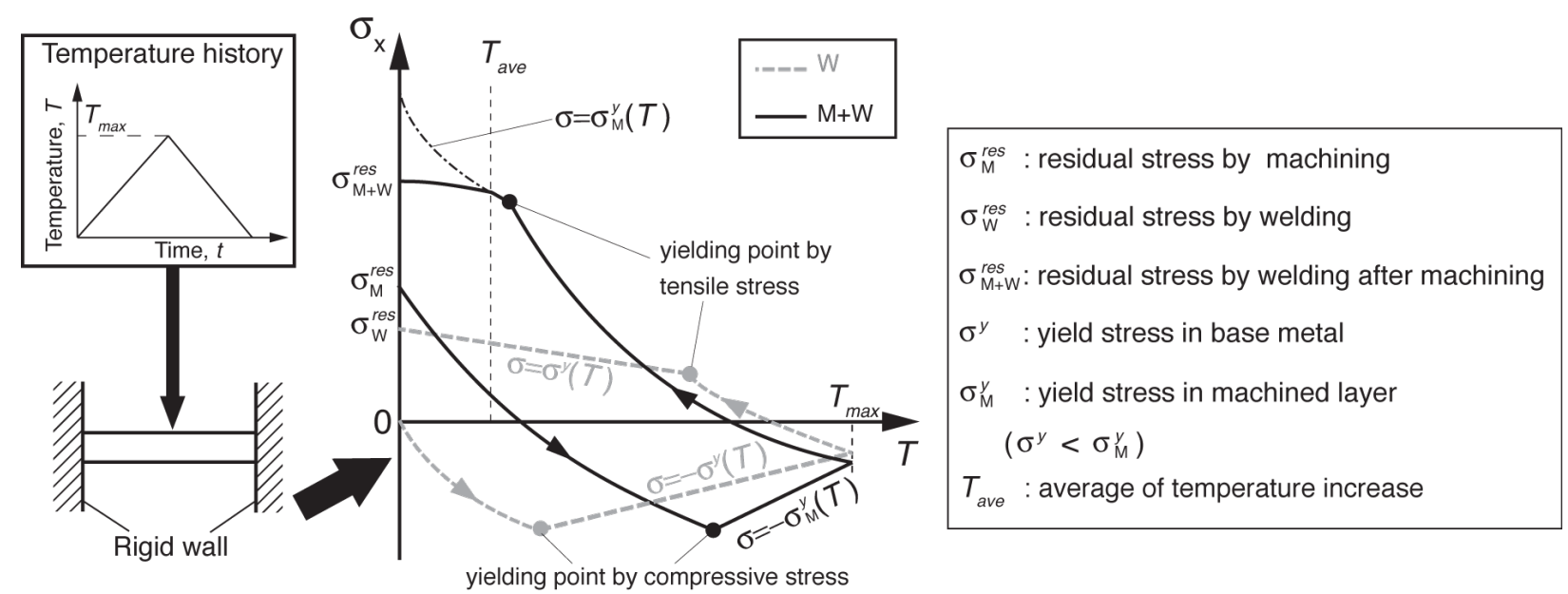

Fig. 7 Relationship between temperature and stress in welding direction by the both-ends-fixed bar model. 
て検討を行う。まず, 初期応力が異なる場合, 温度上昇 時の圧縮降伏に達する温度が異なるものの, 溶接のみで 生じる塑性ひずみは表面機械加工により導入される塑 性ひずみと比較して十分に小さい，そのため，降伏応力 に対してはほとんど影響せず，圧縮応力による降伏以降 の挙動は, Fig. 7 に示した $\mathrm{M}+\mathrm{W}$ の履歴とほぼ同様であ ると考えられる。材料の加工硬化が違う場合に関しては, 圧縮降伏に達する温度, 降伏以降の $T_{\text {max }}$ に達するまでの 挙動は異なる。しかしながら, 高温では, 応力-ひずみ関 係が弾完全塑性挙動に近くなることから， $T_{\text {max }}$ 到達時の 降伏応力に大きな差は生じないと考えられる。したがっ て, 加工硬化が異なる場合においても, 冷却時に引張応 力が発生, 増加する挙動に関してはほぼ差は生じないと 考えられる. そして, 引張応力による降伏が生じるが, 降伏時の温度と $T_{\text {ave }}$ に大きな差がない場合, また, 降伏 が生じずに $T_{\text {ave }}$ に到達する場合を考えると, 加工硬化の 違いに起因した残留応力の差は生じないものと考えら れる. 以上のようなことが生じた結果, どのような条件 で表面機械加工後を行った場合においても, 溶接後の極 大残留応力は同様の值を示したものと推察される.

$$
4 \text { 結 言 }
$$

本研究では, 原子力発電プラントに顕在化している SCC の重要な因子である残留応力に関して, 配管の溶接 接合過程である表面機械加工後の溶接により発生する残 留応力分布に注目し, 残留応力分布に及ぼす表面機械加 工およびビードオンプレート溶接条件の影響に関して検 討を行った．得られた主な結果を以下に示す.

（1）どの条件を用いて表面機械加工を施した場合におい ても，後にビードオンプレート溶接を施すことによ り，溶接熱影響部において極大残留応力が発生し， その值はどの条件においてもほぼ同等であることを 示した.

（2）極大残留応力の発生位置は，表面機械加工条件にほ ぼ依存せず同様の位置に発生したが，溶接入熱の増 加とともに溶接中心から離れた位置において発生す ることを示した.

（3） SQ の溶接条件ではおよそ $12 \mathrm{~mm}$ 以上, LQ の溶接条 件ではおよそ $20 \mathrm{~mm}$ 以上の領域において, 溶接線お よび溶接直交方向の残留応力分布は, 表面機械加工 および溶接条件により影響を受けることを示した。

（4）両端固定棒モデルに対して，表面機械加工の影響を 高い降伏応力を有する領域として考慮することによ り, 表面機械加工後のビードオンプレート溶接によ り生じる極大残留応力の発生を検討可能であると考 えられる。

本研究は, 研究拠点形成費補助金グローバル COE プロ グラム「構造・機能先進材料デザイン教育研究拠点」（大 阪大学), および, 卓越した大学院拠点形成支援補助金 (大
阪大学）の研究費支援のもとに実施された。ここに感謝 の意を表します.

\section{参 考 文 献}

1) Y. Okamura, A. Sakashita, T. Fukuda, H. Yamashita and T. Futami, "Latest SCC issues of core shroud and recirculation piping in Japanese BWRs", Transaction of the 17th International Conference on Structural Mechanics in Reactor Technology, WGO1-1 (2003).

2) The Japan Society of Mechanical Engineers, "Codes for Nuclear Power Generation Facilities - Rules on Fitnessfor-Service for Nuclear Power Plants - ", JSME S NA 1-2008 (2008).

3) G. Nakayama, Y. Sakakibara, T. Fujii, Y. Shimamura and K. Tohgo, "The contribution of the fracture mechanics for testing method which evaluates stress corrosion cracks initiation to propagation process", Journal of the Society of Material Science, Japan, Vol. 59, No. 12, pp. 890-899 (2010).

4) R. N. Parkins, "Strain rate effects in stress corrosion cracking", Corrosion, Vol. 46, No. 3, pp. 178-189 (1990).

5) R. Ihara, T. Hashimoto and M. Mochizuki, "Variation behavior of residual stress distribution by manufacturing processes in welded pipes of austenitic stainless steel", Journal of the Society of Material Science, Japan, Vol. 61, No. 12, pp. 961-966 (2012).

6) K. Takeda, A. Taniyama, T. Kudo, H. Uchida and J. Mizuki, "SCC behavior at hardened surface layer of 316 (LC) in water on high temperature", Zairyo-to-Kankyo, Vol. 58, pp.228-233 (2009).

7) B. B. He, "Introduction to two-dimensional X-ray diffraction”, Powder Diffraction, Vol. 18, pp. 71-85 (2003).

8) E. Kröner, "Berechung der elastischen konstanten des vierkristalls aus den konstanten des einkristalls", Zeiteschrift Physik, Vol.151, pp504-518 (1958).

9) K. Satoh and T. Ohnishi, "Transient thermal stresses of weld heat-affected zone by both-ends-fixed bar analogy", Journal of the Japan Welding Society, Vol. 38, No. 4, pp. 359-371 (1969).

10) S. Matsuoka, "Relationship between $0.2 \%$ proof stress and Vickers hardness of work-hardened low carbon austenitic stainless steel, 316SS", Transactions of the Japan Society of Mechanical Engineers, Series A, Vol. 79, No. 698, pp. 1535-1541 (2004).

11) H. Mori, J. Katsuyama, M. Mochizuki, K. Nishimoto and M. Toyoda, "Study on mechanism of intergranular stress corrosion cracking and analysis of residual stress and work hardening in welds of low-carbon austenitic stainless steel with hard surface machining", Zairyo-to-Kankyo, Vol. 56, No. 12, pp. 568-575 (2007). 